\title{
Effect of environmental temperature on muscle protein turnover and heat production in tube-fed broiler chickens
}

\author{
BY VITUS D. YUNIANTO*, K. HAYASHI $\dagger$, S. KANEDA, A. OHTSUKA AND Y. TOMITA \\ Department of Biochemical Science and Technology, Faculty of Agriculture, Kagoshima University, \\ 1-21-24 Korimoto, Kagoshima 890, Japan
}

(Received 3 June 1996 - Revised 16 September 1996 - Accepted 4 October 1990)

\begin{abstract}
The present experiments were undertaken to investigate the effects of environmental temperatures on growth, abdominal fat content, rate of muscle protein turnover, and heat production in tube-fed intact male broiler chickens. Plasma concentrations of thyroxine $\left(T_{4}\right)$, triiodothyronine $\left(T_{3}\right)$, and corticosterone (CTC) were also examined. Chicks (15 d old) were kept at different environmental temperatures $\left(16,19,22,25,28,31\right.$, and $\left.34^{\circ}\right)$ and given the experimental diet (200 g crude protein/ $\mathrm{kg}, 13.57 \mathrm{MJ} / \mathrm{kg}$ metabolizable energy) by tube three times daily throughout the $12 \mathrm{~d}$ experimental period. In the hot conditions, except for $34^{\circ}$, body-weight gain was significantly higher than in the cold conditions. Thus, food conversion ratios (food : gain ratios) were lower when the birds were exposed to the hot conditions other than $34^{\circ}$. Likewise, abdominal fat content was significantly increased, and heat production was lower in the groups kept under the hot conditions other than $34^{\circ}$. The rate of skeletal muscle protein turnover and plasma concentration of CTC were decreased when the birds were exposed to hot conditions other than $34^{\circ}$, suggesting a role of CTC in the regulation of muscle protein turnover. Plasma concentrations of $T_{4}$ and $T_{3}$ were significantly decreased as environmental temperature increased. These results clearly show that plasma concentrations of thyroid hormones and CTC are associated with accelerated muscle protein turnover and heat production.
\end{abstract}

Environmental temperature: Muscle protein turnover: Heat production: Thyroid hormones: Corticosterone

It is well known that ambient temperature influences the growth of animals. The reduced growth due to high ambient temperature has long been believed to be caused by reduced food intake (Cowan \& Michie, 1978; Hurwitz et al. 1980; Howlider \& Rose, 1987; Sinurat et al. 1987). It has been reported that food intake is inversely related to environmental temperature in chickens (McDonald et al. 1981; Suk \& Washburn, 1995). Thus, lowered food efficiency is a common phenomenon observed under hot conditions. However, Howlider \& Rose (1987) have observed that the reduction in growth does not parallel the reduction in food intake. It is suggested therefore, that factors other than food intake and digestibility exist, which cause growth depression under high environmental temperatures (Dale \& Fuller, 1980; Howlider \& Rose, 1987; Geraert et al. 1996a). On the other hand, it is also well known that high environmental temperature increases mortality in broiler chickens (Hayashi et al. 1990; Lott, 1991; van der Hel et al. 1991; Geraert et al. 1996a). The positive relationship between food intake and mortality is documented (Hayashi $e t$ al.

\footnotetext{
* Present address: The United Graduate School of Agricultural Sciences, Kagoshima University, Japan. $\dagger$ For reprints.
} 
1990). However, the mechanism underlying the effect of environmental temperature on food intake, metabolism and mortality is still unclear.

The rate of skeletal muscle protein turnover is influenced by environmental temperatures (Hayashi et al. 1990, 1992, 1993). Both protein synthesis and breakdown are energetically expensive and thus environmental temperature intensely influences the growth of animals (Harris et al. 1987). This might be caused by changes in endocrine functions. Hayashi et al. (1992) have reported that the lower protein breakdown at high temperatures can be normalized by dietary thyroxine $\left(T_{4}\right)$.

Although only a few studies are available concerning heat production, it seems to be important to evaluate the effect of environmental temperatures on this variable (see Chwalibog \& Eggum, 1989). The rate of heat production, which is regulated by the nervous and endocrine systems, is greatest at low temperatures (Yousef, 1985). Geraert $e t$ al. (1996a) have reported that heat production is decreased when birds are exposed to heat. The reduction in heat production is correlated with reduced serum $T_{4}$ and serum triiodothyronine $\left(T_{3}\right)$ levels (Williamson et al. 1985). The decrease in metabolizable energy (ME) intake that occurs with increasing environmental temperature is correlated with decreased heat production (Li et al. 1992). Williamson et al. (1985) reported that the decrease in serum $\mathrm{T}_{3}$ was more strongly correlated with the reduction in food intake than the reduction in $\mathrm{T}_{\mathbf{4}}$. However, the relations between environmental temperature and food intake, heat production and plasma levels of corticosterone (CTC) and thyroid hormones have yet to be clarified.

In the present study three experiments were conducted using the tube-fed broiler chicken, to clarify the effect of a wide range of environmental temperatures on the growth, abdominal fat content, rate of muscle protein turnover, heat production and plasma levels of $\mathrm{T}_{4}, \mathrm{~T}_{3}$, and CTC. Temperatures tested were 25, 28 and $31^{\circ}$ in Expt 1;19,22 and $25^{\circ}$ in Expt 2; and 16, 25 and $34^{\circ}$ in Expt 3. We report that CTC may play an important role in the regulation of skeletal muscle protein turnover in chickens.

\section{MATERIALS AND METHODS}

\section{Animals and schedule}

Fifty 1-d-old male broiler chickens of the Chunky strain in each experiment were supplied by a local commercial hatchery (Kumiai Hina Centre, Kajiki, Kagoshima, Japan). They were housed in electrically heated battery brooders and were provided with water and a commercial starter diet ad libitum for the first $12 \mathrm{~d}$. On day 12, eighteen birds of similar body weight (about 324 (SD 20) g) were selected and grouped.

\section{Experimental diet and feeding}

The present study consisted of three experiments conducted under similar conditions except environmental temperature. Birds were individually housed in wire-bottomed aluminium cages (height $490 \times$ width $400 \times$ depth $670 \mathrm{~mm}$ ), and there were six replications per treatment. Chicks were preconditioned by feeding a basal diet (13.57 MJ/kg ME and $200 \mathrm{~g}$ crude protein $/ \mathrm{kg}$ ) made mainly from ground yellow maize, dehydrated lucerne (Medicago sativa) meal, and purified soyabean meal. The nutrient composition of the diet is shown in Table 1. The basal diet was fed ad libitum during the preconditioning period (from 12 to $15 \mathrm{~d}$ of age). During the experimental period (from 15 to $27 \mathrm{~d}$ of age), all the chicks were tube-fed three times daily (at 10.00, 15.00 and 19.00 hours). The birds were given daily $100 \%$ of the amount of food which they would be 
Table 1. Composition of the experimental diet

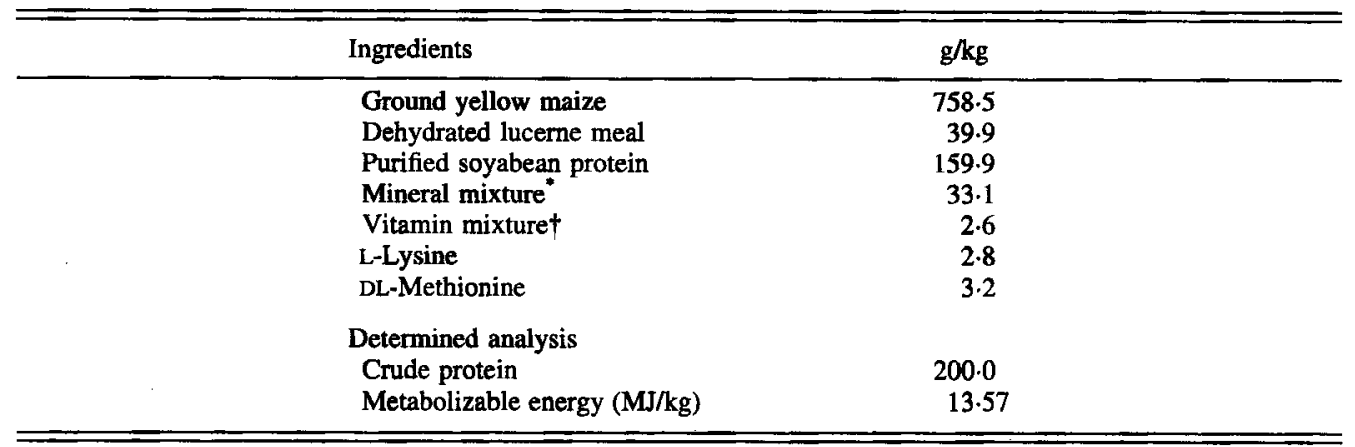

*Provided (/kg diet): $\mathrm{CaCO}_{3} 212 \mathrm{~g}, \mathrm{CaHPO}_{4} 664 \mathrm{~g}, \mathrm{NaCl}_{113} \mathrm{~g}, \mathrm{MnSO}_{4} .4 \mathrm{H}_{2} \mathrm{O} 6.6 \mathrm{~g}, \mathrm{ZnSO}_{4} .7 \mathrm{H}_{2} \mathrm{O} 4 \mathrm{~g}, \mathrm{FeSO}_{4} 5.9 \mathrm{~g}$, $\mathrm{CuSO}_{4} .7 \mathrm{H}_{2} \mathrm{O} 233 \mathrm{mg}, \mathrm{NaTO}_{3} 16 \mathrm{mg}, \mathrm{H}_{2} \mathrm{SeO}_{3} 6 \mathrm{mg}$.

† Provided ( $/ \mathrm{kg}$ diet): retinol $525 \mathrm{mg}$, cholecalciferol $5 \mathrm{mg}$, riboflavin $2.5 \mathrm{~g}$, thiamine $1 \mathrm{~g}$, pyridoxine $0.5 \mathrm{~g}$, cyanocobalamin $10 \mathrm{mg}$, pantothenic acid $4 \mathrm{~g}$, nicotinic acid $10 \mathrm{~g}$, menadione $250 \mathrm{mg}$, pteroylglutamic acid $200 \mathrm{mg}$, choline chloride $300 \mathrm{mg}$, biotin $25 \mathrm{mg}$, dl- $\alpha$-tocopheryl acetate $2.5 \mathrm{~g}$.

expected to consume ad libitum at $25^{\circ}$ to equalize intakes at the various temperatures. The experiments were conducted in temperature-controlled rooms with a $14 \mathrm{~h}$ light- $10 \mathrm{~h}$ dark cycle. Each experiment also included one group at $25^{\circ}$ to demonstrate the comparability of the experiments; this was done because of the limited number of temperature-controlled rooms and respiratory chambers available. Temperatures of the rooms were 25,28 and $31^{\circ}$ in Expt 1; 19, 22 and $25^{\circ}$ in Expt 2; and 16, 25 and $34^{\circ}$ in Expt 3. Relative humidity was maintained at 50-70\% for all groups throughout the experiment. Body weights were determined every $3 \mathrm{~d}$. At the end of the experimental period, rectal temperature was measured at 10.00 hours, and the birds were killed by decapitation. Blood samples were collected into heparinized test-tubes for determination of plasma concentrations of $T_{4}, T_{3}$ and CTC. The birds were dissected to remove pairs of breast muscles (musculus pectoralis profundus and musculus pectoralis superficialis), abdominal fat, heart, liver, adrenal glands and thyroid glands. Pectoral muscle weights were used as measures of skeletal muscle growth because pectoral muscles are easily dissected and their lipid contents are lower than those of the thigh muscles. The rates of growth of breast muscles are similar to those of thigh muscles between 2 and 4 weeks of age (Kang et al. 1985).

\section{Measurement of heat production}

On day 23 , heat production was measured by open-circuit calorimetry. The calorimetry apparatus consisted of chamber (height $270 \times$ width $360 \times$ depth $520 \mathrm{~mm}$ ), air-flow meter (Model RK1350V, Kofloc Co. Ltd, Tokyo, Japan) and pump (Hiblow Air Pump, Model SPP-3EBS, Techno Takatsuki Co. Ltd, Osaka, Japan). The flow rate was adjusted by the air-flow meter and $\mathrm{O}_{2}$ and $\mathrm{CO}_{2}$ concentrations in expired air from the pump were monitored by an $\mathrm{O}_{2}$ meter (Yokogawa Model OX16, Yokogawa Electric Co., Tokyo, Japan) and a $\mathrm{CO}_{2}$ meter (Riken Keiki, Model RI.411A, Riken Keiki Co. Ltd, Tokyo, Japan), respectively. Both detectors are able to measure concentrations as low as $0.1 \mathrm{ml} / \mathrm{l}$. $\mathrm{O}_{2}$ consumption and $\mathrm{CO}_{2}$ production were measured from 10.00 to 15.00 hours. The air flow rate was 1.20 litres/min, $\mathrm{O}_{2}$ consumption and $\mathrm{CO}_{2}$ production were calculated from the decrease (\%) in $\mathrm{O}_{2}$ concentration and increase $(\%)$ in $\mathrm{CO}_{2}$ concentration in the chamber 
over 60 min. $\mathrm{O}_{2}$ consumption and $\mathrm{CO}_{2}$ production were expressed as $\mathrm{ml} / \mathrm{kg}$ metabolic weight $\left(\mathrm{W}^{0.75}\right)$ per min. Heat production was estimated according to the method of Romijn \& Lockhorst (1961), as follows:

heat production $(\mathrm{J} / \mathrm{h})=16.20 \times \mathrm{O}_{2}$ consumption (litres $\left./ \mathrm{h}\right)+5 \times \mathrm{CO}_{2}$ production (litres $/ \mathrm{h}$ ).

\section{Measurements of $N^{\tau}$-methylhistidine $\left(N^{\tau}-M H\right)$ and rates of muscle protein breakdown and synthesis}

Excreta samples were collected daily for $3 \mathrm{~d}$ starting at $24 \mathrm{~d}$ of age and pooled to measure rate of muscle protein breakdown by $\mathrm{N}^{\tau}-\mathrm{MH}$. The excreta samples were stored at $-20^{\circ}$ until analysed. $\mathbf{N}^{\tau}-\mathbf{M H}$ contents in the excreta were analysed to estimate muscle protein breakdown by the method of Hayashi et al. (1987) using HPLC. Dietary and muscle $\mathrm{N}^{\tau}$ MH contents were similarly analysed.

The fractional rate of muscle protein breakdown was estimated on the assumption that skeletal muscle comprises $293 \mathrm{~g} / \mathrm{kg}$ live weight in the 4-week-old male broiler chicken, and that $\mathrm{N}^{\tau}-\mathrm{MH}$ concentration of muscle is $0.606 \mu \mathrm{mol} / \mathrm{g}$ (Maeda et al. 1984). Thus, the pool size of $\mathrm{N}^{\tau}-\mathrm{MH}$ in the skeletal muscle was estimated to be $178 \mu \mathrm{mol} / \mathrm{kg}$ body weight. Because the diet contained $\mathrm{N}^{\tau}-\mathrm{MH}(0.04 \mu \mathrm{mol} / \mathrm{g})$, it was subtracted from the total excreted $\mathrm{N}^{\tau}$-MH derived from body tissues and this was multiplied by 0.8 to give the excreted $\mathrm{N}^{\tau}$ MH derived from the skeletal muscle as reported by Hayashi et al. (1985).

The fractional breakdown rate was calculated by dividing the amount of excreted $\mathrm{N}^{\tau}$ $\mathrm{MH}$, derived from skeletal muscle, by the amount of $\mathrm{N}^{t}-\mathbf{M H}$ in the skeletal muscle. No correction was applied for incomplete recovery of $\mathrm{N}^{\tau}-\mathrm{MH}$ (Harris et al. 1987). The rates of muscle protein synthesis were calculated by summation of the fractional rate of breakdown and the fractional rate of growth. The growth rates were calculated from the average fractional increase in body weight during the $12 \mathrm{~d}$ experimental period. Here we assumed that growth rate was linear over time and muscle accretion rate was the same as growth rate.

\section{Measurements of hormones}

Plasma levels of $T_{4}$ and $T_{3}$ were measured by enzyme-immunoassay using commercial kits. Plasma $T_{4}$ concentration was measured by Enzymun-Test ${ }^{\circledR}-T_{4}$ (BoehringerMannheim, Mannheim, Germany). However, we prepared our own $T_{4}$ standard because the $T_{4}$ level in chicken plasma is beyond the range of the standards in the kit. Plasma $T_{3}$ level was measured by Enzymun-Test $T_{3}$, Elsia ${ }^{\circledR}$-Auto $T_{3}$ (International Reagents Corporation, Kobe, Japan).

Plasma level of CTC was measured by the method of Ohtsuka et al. (1995) using HPLC.

\section{Statistical analysis}

Data were analysed using the General Linear Model procedure of the Statistical Analysis System (SAS) software package (Release 6.09, SAS Institute Inc., Cary, NC, USA) with the Duncan's multiple range test of means option. Correlation and regression analyses were performed on individual values. A $P$ value $<0.05$ was considered to be statistically significant. 


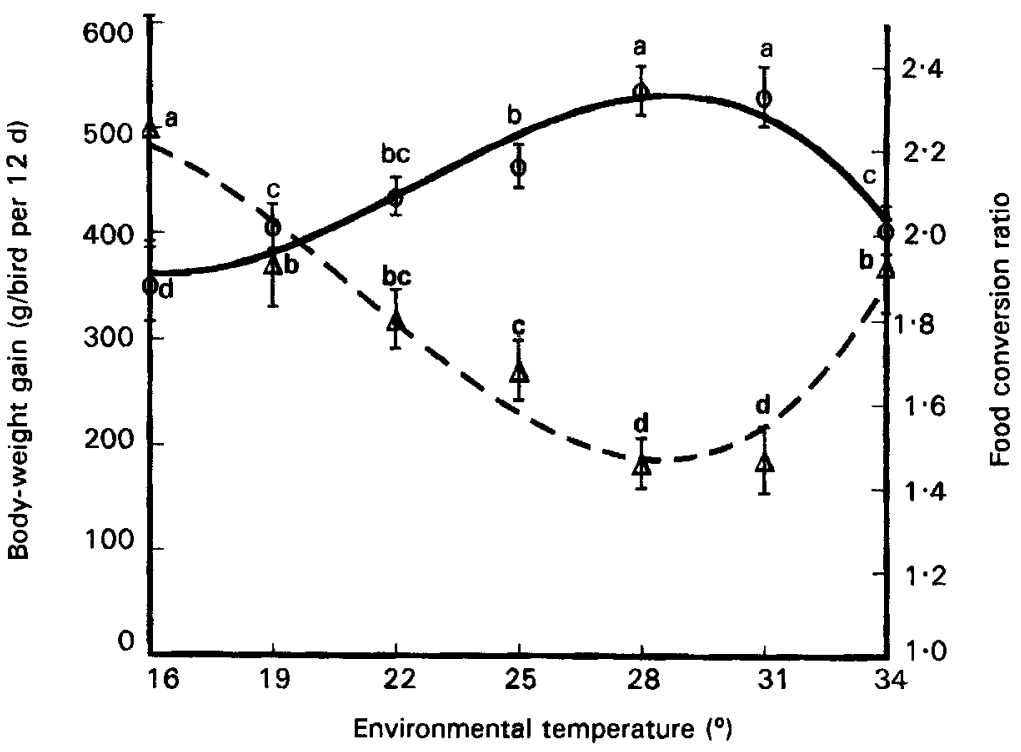

Fig. 1. Relationships of body-weight gain $(\mathrm{O}-\mathrm{O})$ and food conversion ratio $(\Delta--\Delta)$ with environmental temperature in broiler chickens. Values are means and standard deviations for six chickens per temperature group except for $25^{\circ}$ which is the mean of control groups from the three separate experiments represented ( $n$ 18). For details of procedures, see pp. 898-899. Values not sharing a common letter were significantly different, $P<0.01$. The relationships are described by the equations: $Y=-0.18 X^{3}+12.08 X^{2}-251.74 X+2029.02(r 0.96)$ where $Y$ is body-weight gain and $X$ is environmental temperature; and $Y=0.0005 X^{3}-0.03 X^{2}+0.58 X-1.06(r 0.97)$ where $Y$ is food conversion ratio and $X$ is environmental temperature.

\section{RESULTS}

Because there was no significant difference between the values for the control groups $\left(25^{\circ}\right)$ in the three experiments, the results of the three experiments have been pooled. Relations between environmental temperature and body-weight gain and food conversion ratio (food:gain ratio) are shown in Fig. 1. Regression analysis gave the following highly significant $(r 0.96)$ relationship: $Y=-0.18 X^{3}+12.08 X^{2}-251.74 X+2029.02$, where $Y$ is body-weight gain ( $\mathrm{g} / \mathrm{bird}$ per $12 \mathrm{~d}$ ) and $X$ is environmental temperature. Between 16 and $28^{\circ}$ the increase in body-weight gain with increasing temperature was almost linear, but beyond $31^{\circ}$ there was a sharp decline in growth rate. The effect of temperature on food conversion ratio was the opposite, because all the birds were tube-fed the same amount of diet. The equation was $Y=0.0005 X^{3}-0.03 X^{2}+0.58 X-1.06(r 0.97)$ where $Y$ is food conversion ratio and $X$ is environmental temperature.

Weights of breast muscles, heart, liver, adrenal glands and thyroid glands are shown in Table 2. Temperature had no effect on either pectoral profundus muscle or pectoral superficial muscle weights. Heart weight tended to decrease when environmental temperature increased and at $16^{\circ}$ it was significantly higher than at other temperatures. Liver weight tended to decrease as temperature increased up to $31^{\circ}$. At $34^{\circ}$, liver weight was higher than those at $22,25,28$ and $31^{\circ}$. Adrenal gland weights were higher at 16,19 , 22 and $34^{\circ}$ than those at 25,28 and $31^{\circ}$. Thyroid gland weights decreased, as expected, as environmental temperature increased. Rectal temperature was not affected by the temperatures tested. 


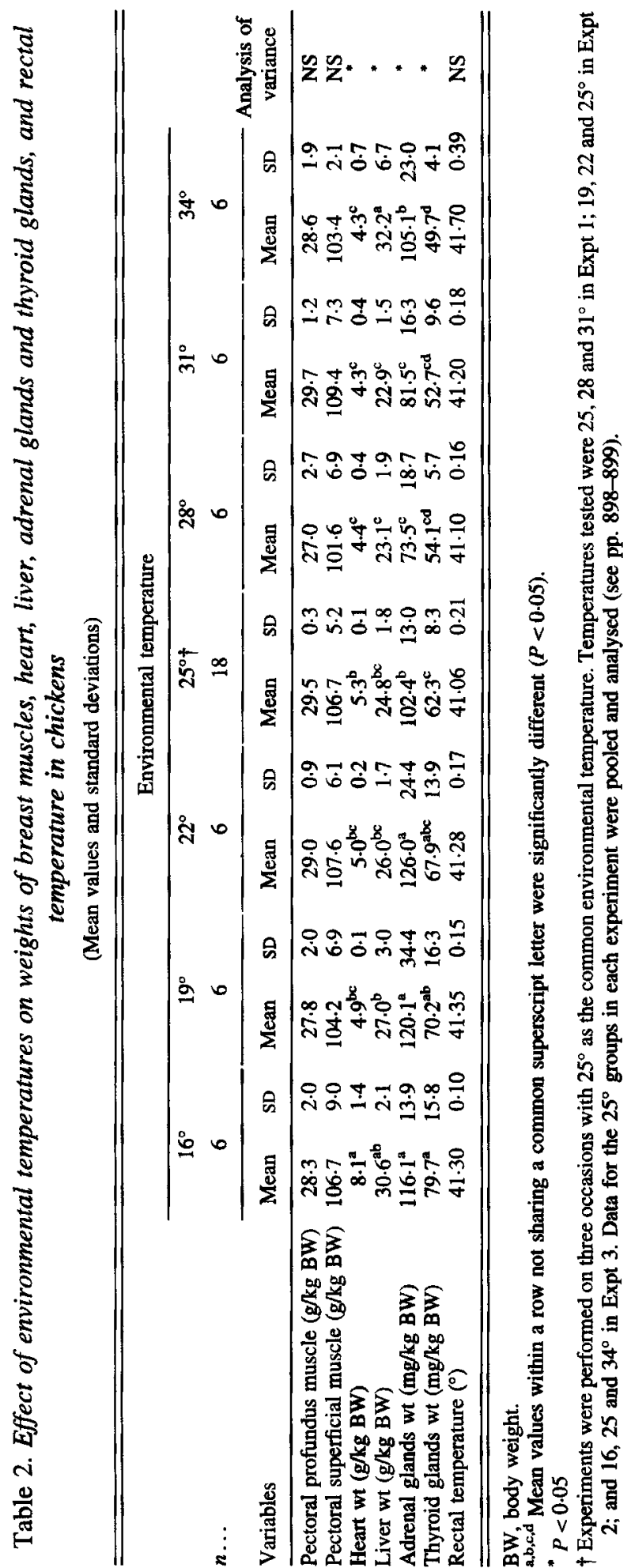




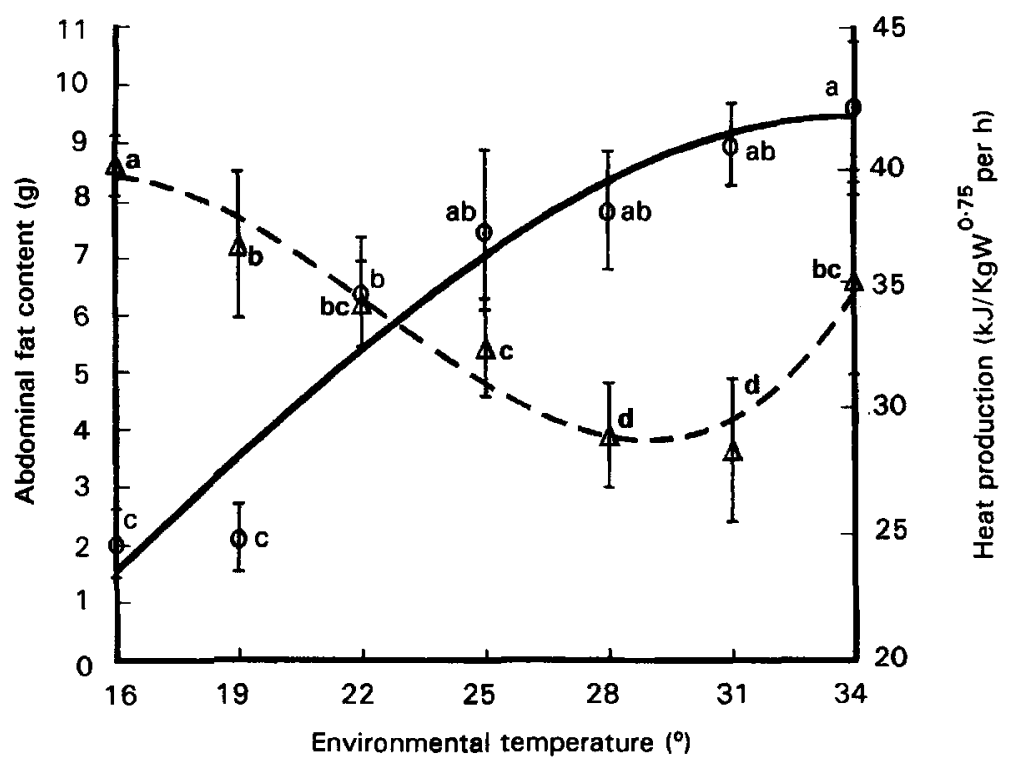

Fig. 2. Relationships of abdominal fat content $(\mathrm{O}-\mathrm{O})$ and heat production $(\triangle--\Delta)$ with environmental temperature in broiler chickens. Values are means and standard deviations for six chickens per temperature group except for $25^{\circ}$ which is the mean of control groups from the three separate experiments represented ( $n$ 18). For details of procedures, see pp. 898-900. Values not sharing a common letter were significantly different, $P<0.01$. The relationships are described by the equations: $Y=-0.0007 X^{3}-0.03 X^{2}+0.16 X-6.48(r 0.97)$ where $Y$ is abdominal fat content and $X$ is environmental temperature; and $Y=0.0091 X^{3}-0.61 X^{2}+12.35 X-40.34(r 0.97)$ where $Y$ is heat production and $X$ is environmental temperature.

The effect of environmental temperature on heat production, expressed per unit metabolic body size, is shown in Fig. 2. The equation is $Y=0.0091 X^{3}-0.61 X^{2}+$ $12.35 X-40.34(r 0.97)$ where $Y$ is heat production and $X$ is environmental temperature. Heat production decreased linearly with increasing temperature up to about $30^{\circ}$. However, it increased with any further increase in temperature.

Abdominal fat content is also shown in Fig. 2. The equation is $Y=-0.0007 X^{3}-$ $0.03 X^{2}+0.16 X-6.48(r 0.97)$ where $Y$ is abdominal fat content $(\mathrm{g})$ and $X$ is environmental temperature. Abdominal fat content increased almost linearly with increasing temperature. Abdominal fat in birds kept at $34^{\circ}$ was five times that of birds kept at $16^{\circ}$.

The regression equations between rates of muscle protein synthesis and breakdown estimated from $\mathbf{N}^{\tau}-\mathbf{M H}$ excretion and environmental temperature were calculated as follows: $Y=0.0018 X^{3}-0.13 X^{2}+2.97 X-12.15(r 0.98)$ where $Y$ is muscle protein synthesis rate (\% per d) and $X$ is environmental temperature; $Y=0.0022 X^{3}-$ $0.15 X^{2}+3.37 X-18.62(r 0.99)$ where $Y$ is muscle protein breakdown rate (\% per d) and $X$ is environmental temperature. They are shown in Fig. 3. The rates of both protein synthesis and breakdown were similarly affected by environmental temperature. From $19^{\circ}$ to $28^{\circ}$, decreases in both synthesis and breakdown occurred, followed by increases at temperatures above $28^{\circ}$. Between $16^{\circ}$ and $19^{\circ}$, little change was observed.

Plasma levels of $T_{4}$ and $T_{3}$ are presented in Fig. 4. There were significant correlations between the hormones and temperature as follows: $Y=0.0067 X^{3}-0.44 X^{2}+5.57 X+$ $66.72(r 0.99)$ where $Y$ is plasma level of $\mathrm{T}_{4}(\mu \mathrm{g} / \mathrm{l})$ and $X$ is environmental temperature; 


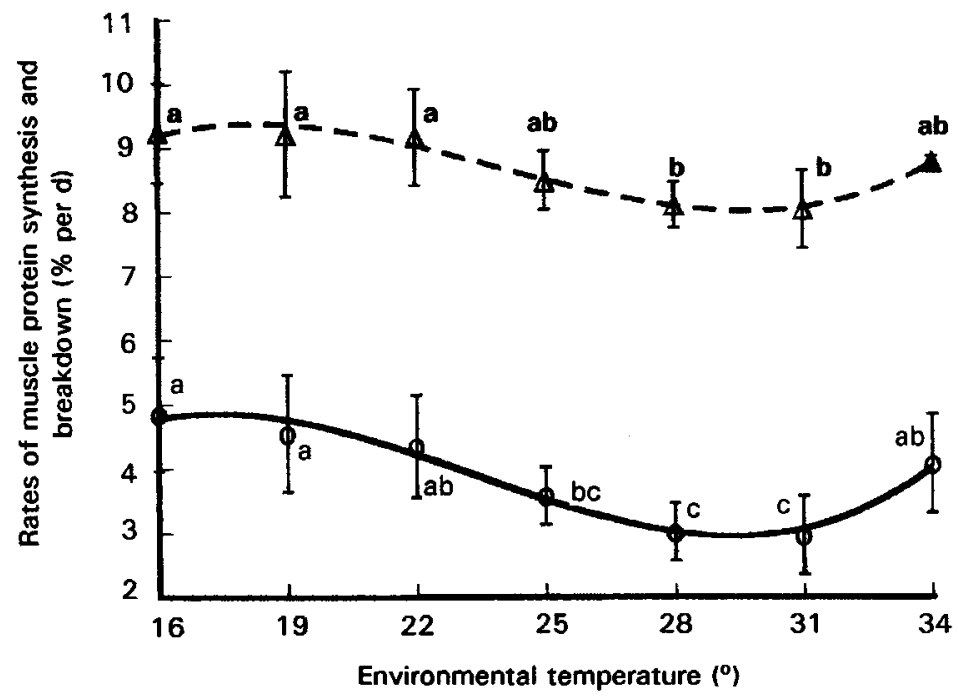

Fig. 3. Relationships of rate of muscle protein breakdown $\left(\mathrm{O}^{-} \mathrm{O}\right)$ and rate of muscle protein synthesis $(\Delta---\Delta)$ estimated from $\mathbf{N}^{\tau}$-methylhistidine with environmental temperature in broiler chickens. Values are means and standard deviations for six chickens per temperature group except for $25^{\circ}$ which is the mean of control groups from the three separate experiments represented $(n 18)$. For details of procedures, see pp. 898-900. Values not sharing a common letter were significantly different, $P<0.01$. The relationships are described by the equations: $Y=0.0018 X^{3}-$ $0.13 X^{2}+2.97 X-12.15(r 0.98)$ where $Y$ is muscle protein synthesis rate and $X$ is environmental temperature; and $Y=0.0022 X^{3}-0.15 X^{2}+3.37 X-18.62(r \quad 0.99)$ where $Y$ is muscle breakdown rate and $X$ is environmental temperature.

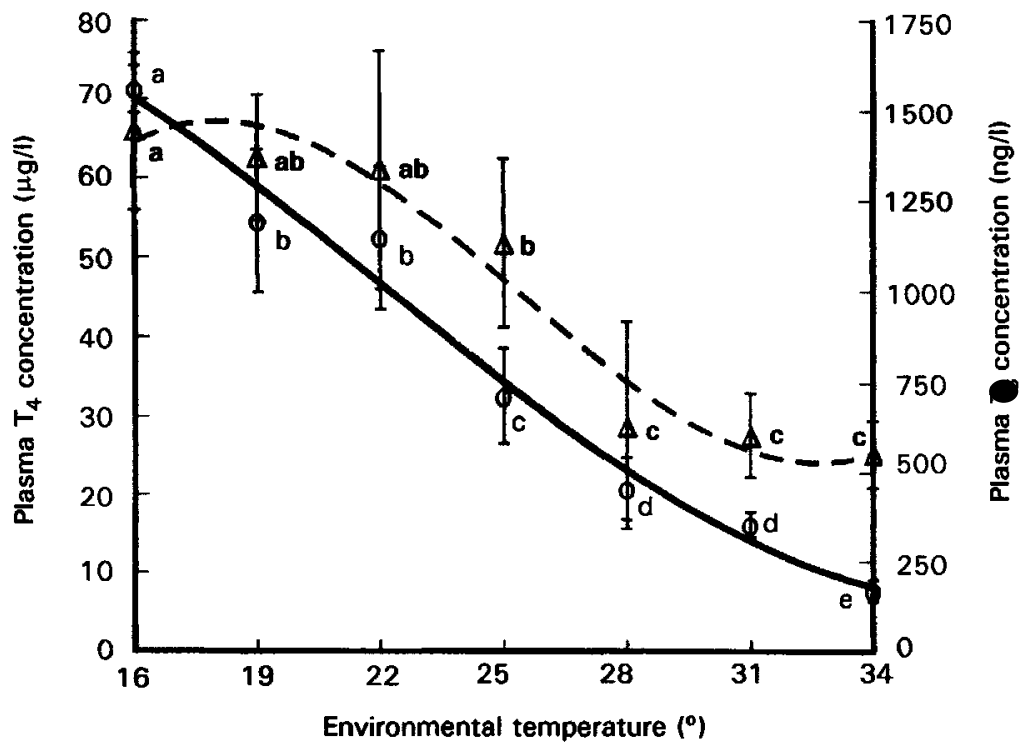

Fig. 4. Relationships of plasma thyroxine $\left(\mathrm{T}_{4}\right)$ concentration $(\mathrm{O}-\mathrm{O})$ and plasma triiodothyronine $\left(\mathrm{T}_{3}\right)$ concentration $(\triangle--\triangle)$ with environmental temperature in broiler chickens. Values are means and standard deviations for six chickens per temperature group except $25^{\circ}$ which is the mean of control groups from the three separate experiments represented ( $n$ 18). For details of procedures, see pp. 898-900. Values not sharing a common letter were significantly different, $P<0.01$. The relationships are described by the equations: $Y=0.0067 X^{3}-0.44 X^{2}+5.57 X+66.72(r 0.99)$ where $Y$ is plasma $\mathrm{T}_{4}$ concentration and $X$ is environmental temperature; and $Y=0.5967 X^{3}-45.26 X^{2}+1048.03 X-6208.61$ ( $r$ 0.98) where $Y$ is plasma $T_{3}$ concentration and $X$ is environmental temperature. 


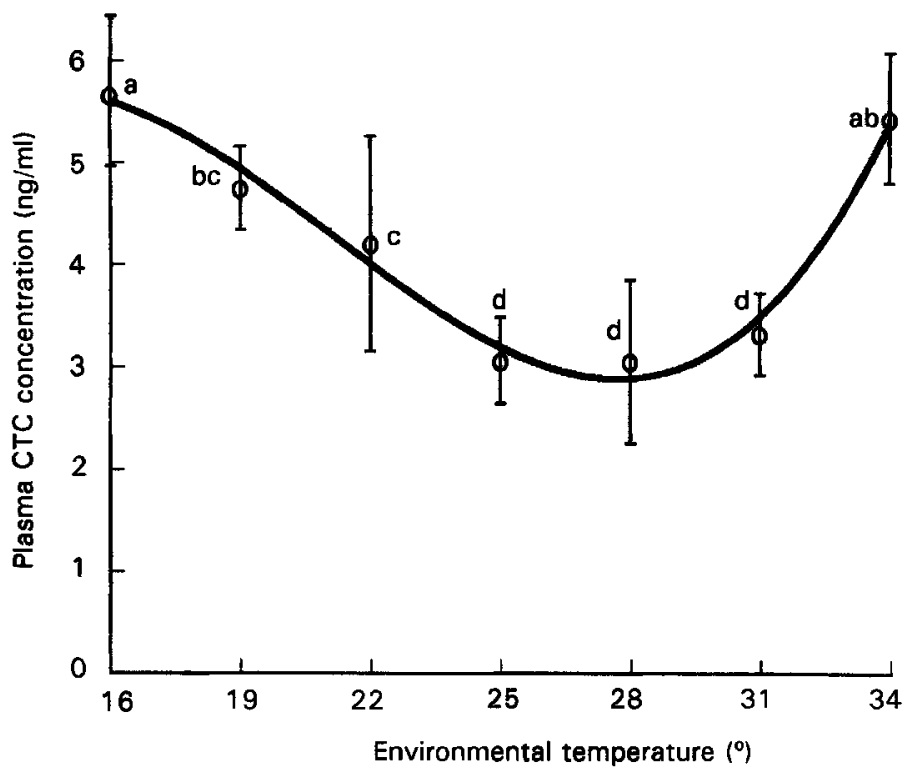

Fig. 5. Relationship between plasma corticosterone (CTC) concentration and environmental temperature in broiler chickens. Values are means with their standard deviations for six chickens per temperature group except for $25^{\circ}$ which is the mean of control groups from the three separate experiments represented $(n$ 18). For details of procedures, see pp. 898-900. Values not sharing a common letter were significantly different, $P<0.01$. The relationship is described by the equation: $Y=0.003 X^{3}-0.15 X^{2}+2.90 X-11.61(r 0.99)$ where $Y$ is plasma $C T C$ concentration and $X$ is environmental temperature.

$Y=0.5967 X^{3}-45.26 X^{2}+1048.03 X-6208.61(r 0.98)$ where $Y$ is plasma level of $\mathrm{T}_{3}$ (ng/l) and $X$ is environmental temperature. However, changes in $T_{4}$ concentration were more pronounced than those of $T_{3}$.

A clear correlation was also evident between plasma CTC level and environmental temperature (Fig. 5). The equation was $Y=0.003 X^{3}-0.15 X^{2}+2.90 X-11.61(r 0.99)$ where $Y$ is plasma CTC level and $X$ is environmental temperature. From $16^{\circ}$ to $28^{\circ}$, plasma CTC decreased with increasing temperature and it then increased between $28^{\circ}$ and $34^{\circ}$.

Relations between plasma CTC level and rates of muscle protein turnover are presented in Fig. 6(a) and Fig. 6(b). There was a linear positive correlation with the rate of muscle protein breakdown (Fig. 6(a)) and the equation was $Y=0.56 X+1.54(r 0.84$, $P<0.01)$ where $Y$ is muscle protein breakdown rate and $X$ is plasma CTC level. The relation with rate of muscle protein synthesis is shown in Fig. 6(b). The equation was $Y=0.37 X+7.19(r 0.78, P<0.01)$ where $Y$ is muscle protein synthesis rate and $X$ is plasma CTC level.

\section{DISCUSSION}

It is well documented that growth rate and food intake are changed by environmental temperature (Howlider \& Rose, 1987; Sinurat et al. 1987; Hayashi et al. 1992; Li et al. 1992; Wiernusz \& Teeter, 1993; Daghir, 1995; Geraert et al. 1996a). Because reduced food intake at high environmental temperatures limits the scope of ad libitum feeding experiments, tube-feeding was adopted in the present experiment. Our results clearly show that if the limits of ad libitum feeding are circumvented, the birds grow faster as the 
(a)

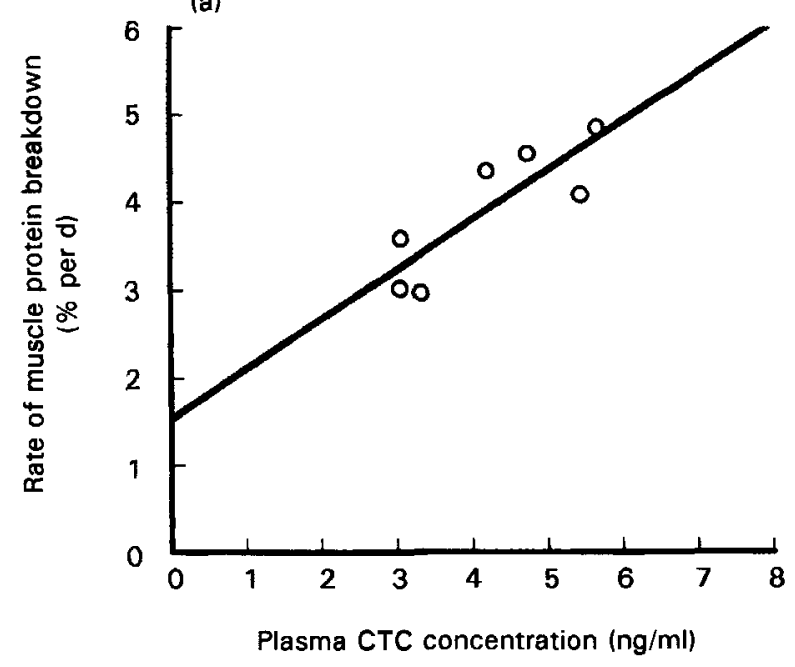

(b)

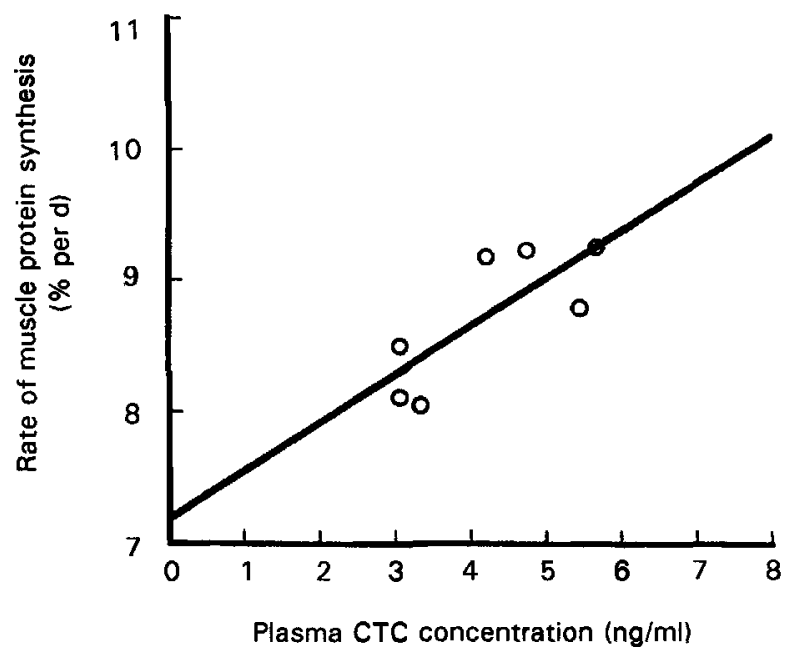

Fig. 6. (a) Relationship between plasma corticosterone (CTC) concentration and rate of muscle protein breakdown in broiler chickens. The relationship is described by the equation: $Y=0.56 X+1.54(r 0.84)$ where $Y$ is plasma CTC concentration and $X$ is rate of muscle protein breakdown. (b) Relationship between plasma CTC concentration and rate of muscle protein synthesis in broiler chickens. The relationship is described by the equation: $Y=0.37 X+7 \cdot 19(r 0.78)$ where $Y$ is plasma CTC concentration and $X$ is rate of muscle protein synthesis.

temperature rises from 16 to $31^{\circ}$. Several investigators (Howlider \& Rose, 1987; Sinurat et al. 1987; Mckee \& Harrison, 1995) have reported that exposure of birds to high temperatures results in body-weight losses mainly because food intake is depressed.

The present results also clearly show that increases in environmental temperature give greater savings of food in broiler chickens except at temperatures above $28^{\circ}$, providing birds eat equally. Smith \& Teeter (1987) reported that force-feeding of birds to $16 \%$ above ad libitum intake at high environmental temperatures increased the yield of broiler carcass; 
and thus our results are consistent with their finding. Furthermore, Gross \& Siegel (1993) have reported that food efficiency is reduced only in heat stress environments when birds are fed ad libitum.

It is well documented that abdominal fat content is affected by environmental temperature (Cahaner \& Leenstra, 1992; Leenstra \& Cahaner, 1992; Suk \& Washburn, 1995). This was also clarified in the present study. More energy is dissipated as heat in a cooler environment and thus fat accumulation is decreased. Heat production was dependent on environmental temperature in chickens (Chwalibog \& Eggum, 1989) and in laying hens (Li et al. 1992). However, increased heat production was observed when birds were exposed to $34^{\circ}$. A negative relationship has been observed between heat production and environmental temperature (Chwalibog \& Eggum, 1989; Li et al. 1992). However, it was shown in the present study that when the birds were exposed to temperatures above $31^{\circ}$ heat production was increased. This may relate to the energetic cost of panting although the effects on heat production under such a stress condition might be complicated as has been reported by Wiernusz \& Teeter (1993). The increased plasma concentration of CTC in the present experiment indicates that the birds were under stress. The present results also show that heat stress increases the rate of muscle protein breakdown. The increase in the rate of protein breakdown might raise heat production as was suggested by Hayashi et al. (1990).

The progressive declines of both $T_{4}$ and $T_{3}$ under the hot conditions in the present experiment are consistent with earlier reports (Williamson et al. 1985; Geraert et al. 1993). In the present study, significant differences in thyroid size were also observed. However, Cogburn \& Harrison (1980) and Sinurat et al. (1987) have reported that during exposure to hot conditions, the plasma concentration of $\mathrm{T}_{4}$ increases, and Goldberg et al. (1980) have reported that thyroid hormones appear to be as effective as growth hormone in stimulating growth of muscle. The patterns of plasma concentrations of thyroid hormones and rate of muscle protein breakdown due to the temperature are interesting.

The present study showed that the rates of both muscle protein synthesis and breakdown were higher under hot conditions $\left(34^{\circ}\right)$ than at $31^{\circ}$ while the concentration of $T_{3}$ was lower. These results indicate that there might be changes in other hormonal situations such as CTC during heat stress. Indeed, when the chicks were exposed to hot conditions $\left(34^{\circ}\right)$, plasma CTC concentration was increased and tended to be increased by either the very hot or very cold conditions, showing the stress response. This is consistent with the results of Geraert et al. (1996b) which showed that plasma concentration of CTC is increased by chronic heat exposure. Plasma concentration of CTC and rate of muscle protein breakdown showed similar trends in the present experiment.

From these results it is reasonable to speculate that thyroid hormones and CTC may play roles in regulating rates of both muscle protein synthesis and breakdown in response to environmental temperature. The data also indicated a good correlation between the reduction in heat production and plasma CTC concentration, indicating the role of CTC in regulating heat production under different environmental temperatures.

We conclude from these results that in broiler chickens plasma concentrations of thyroid hormones and CTC accelerate muscle protein turnover and heat production, indicating the importance of the balance of hormones in controlling the rate of muscle protein turnover and heat production in response to environmental temperature.

\section{REFERENCES}

Cahaner, A. \& Leenstra, F. (1992). Effects of high temperature on growth and efficiency of male and female broilers from lines selected for high weight gain, favorable feed conversion, and high or low fat content. Poultry Science 71, 1237-1250. 
Chwalibog, A. \& Eggum, B. O. (1989). Effect of temperature on performance, heat production, evaporative heat loss and body composition in chickens. Archiv für Geflügelkunde 53, 179-184.

Cogburn, L. A. \& Harrison, P. C. (1980). Adrenal, thyroid, and rectal temperature responses of pinealectomized cockerels to different ambient temperatures. Poultry Science 59, 1132-1141.

Cowan, P. J. \& Michie, W. (1978). Environmental temperature and choice feeding of the broiler. British Journal of Nutrition 40, 311-315.

Daghir, N. J. (1995). Nutrient requirement of poultry at high temperatures. In Poultry Production in Hot Climates, pp. 101-123 [N. J. Daghir, editor]. Wallingford: CAB International.

Dale, N. M. \& Fuller, H. L. (1980). Effect of diet composition on feed intake and growth of chicks under heat stress. II. Constant vs cycling temperatures. Poultry Science 59, 1434-1441.

Geraert, P. A., Padilha, J. C. F. \& Guillaumin, S. (1993). Metabolic and endocrine changes induced by heat exposure in chickens. Proceedings of the Nutrition Society 52, 165A.

Geraert, P. A., Padilha, J. C. F. \& Guillaumin, S. (1996a). Metabolic and endocrine changes induced by chronic heat exposure in broiler chickens: growth performance, body composition and energy retention. British Journal of Nutrition 75, 195-204.

Geraert, P. A., Padilha, J. C. F. \& Guillaumin, S. (1996b). Metabolic and endocrine changes induced by chronic heat exposure in broiler chickens: biological and endocrinological variables. British Journal of Nutrition $\mathbf{7 5}$, 205-216.

Goldberg, A. L., Tischler, M., DeMartino, G. \& Griffin, G. (1980). Hormonal regulation of protein degradation and synthesis in skeletal muscle. Federation Proceedings 39, 31-36.

Gross, W. B. \& Siegel, P. B. (1993). General principles of stress and welfare. In Livestock Handling and Transport, pp. 21-33 [T. Grandin, editor]. Wallingford: CAB International.

Harris, C. I., Milne, G. \& McDiarmid, R. (1987). The retention and metabolism of $\mathbf{N}^{\tau}$-methylhistidine by cockerels: implications for the measurement of muscle protein breakdown determined from the excretion of $\mathrm{N}^{\tau}$-methylhistidine in excreta. British Journal of Nutrition 57, 467-478.

Hayashi, K., Kaneda, S., Ohtsuka, A. \& Tomita, Y. (1992). Effects of ambient temperature and thyroxine on protein turnover and oxygen consumption in chicken skeletal muscle. In Proceedings 19th World's Poultry Congress, vol. 2, pp. 93-96 [R. Mulder, editor]. Amsterdam: Ponsen \& Looijen.

Hayashi, K., Kukita, S., Mukai, M., Toyomizu, M. \& Tomita, Y. (1990). Effect of dietary thyroxine on muscle protein metabolism and abdominal fat content in broiler chicken in hot and moderate environments. Japanese Journal of Zootechnical Science 61, 1107-1112.

Hayashi, K., Maeda, Y., Toyomizu, M. \& Tomita, Y. (1987). High performance liquid chromatographic method for the analysis of $\mathrm{N}^{t}$-methylhistidine in food, chicken excreta, and rat urine. Journal of Nutritional Science and Vitaminology 33, 151-156.

Hayashi, K., Michioka, M. \& Tomita, Y. (1993). Interaction of thyroxine and testosterone in stimulating muscle protein breakdown in female broiler chickens. British Poultry Science 34, 1029-1034.

Hayashi, K., Tomita, Y., Maeda, Y., Shinagawa, Y., Inoue, K. \& Hashizume, T. (1985). The rate of degradation of myofibrillar proteins of skeletal muscle in broiler and layer chickens estimated by $\mathrm{N}^{2}$-methylhistidine in excreta. British Journal of Nutrition 54, 157-163.

Howlider, M. A. R. \& Rose, S. P. (1987). Temperature and the growth of broilers. World's Poultry Science Journal 43, 228-237.

Hurwitz, S., Weiselberg, M., Eisner, U., Bartov, I., Riesenfeld, G., Sharvit, M., Niv, A. \& Bornstein, S. (1980). The energy requirements and performance of growing chickens and turkeys as affected by environmental temperature. Poultry Science 59, 2290-2299.

Kang, C. W., Sunde, M. L. \& Swick, R. W. (1985). Growth and protein turnover in the skeletal muscles of broiler chicks. Poultry Science 64, 370-379.

Leenstra, F. \& Cahaner, A. (1992). Effects of low, normal, and high temperatures on slaughter yield of broilers from lines selected for high weight gain, favorable feed conversion, and high or low fat content. Poultry Science 71, 1994-2006.

Li, Y., Ito, T., Nishibori, M. \& Yamamoto, S. (1992). Effects of environmental temperature on heat production associated with food intake and on abdominal temperature in laying hens. British Poultry Science 33, 113-122.

Lott, B. D. (1991). The effect of feed intake on body temperature and water consumption of male broilers during heat exposure. Poultry Science 70, 756-759.

McDonald, P., Edwards, R. A. \& Greenhalgh, J. F. D. (1981). Animal Nutrition, 3rd ed. New York: Longman Inc.

Mckee, J. S. \& Harrison, P. C. (1995). Effects of supplemental ascorbic acid on the performance of broiler chickens exposed to multiple concurrent stressors. Poultry Science 74, 1772-1785.

Maeda, Y., Hayashi, K., Toyohara, S. \& Hashiguchi, T. (1984). Variation among chicken stocks in the fractional rates of muscle protein synthesis and degradation. Biochemical Genetics 22, 687-700.

Ohtsuka, A., Hayashi, K., Kawano, H. \& Tomita, Y. (1995). Determination of corticosterone in chicken plasma by a modified method using high performance liquid chromatography. Japanese Poultry Science 32, $137-141$.

Romijn, C. \& Lokhorst, M. W. (1961). Some aspects of energy metabolism in birds. In Proceedings Second Symposium on Energy Metabolism. Methods and Results of Experiments with Animals. European Association 
for Animal Production Publication no. 10, pp. 49-59 [E. Brouwer and A. J. H. van Es, editors]. Wageningen: EAAP.

Sinurat, A. P., Balnave, D. \& McDowell, G. H. (1987). Growth performance and concentrations of thyroid hormones and growth hormone in plasma of broilers at high temperatures. Australian Journal of Biological Science 40, 443-450.

Smith, R. O. \& Teeter, R. G. (1987). Influence of feed intake and ambient temperature stress on the relative yield of broiler parts. Nutrition Reports International 35, 299-306.

Suk, Y. O. \& Washburn, K. W. (1995). Effects of environment on growth, efficiency of feed utilization, carcass fatness, and their association. Poultry Science 74, 285-296.

van der Hel, W., Verstegen, M. W. A., Henken, A. M. \& Brandsma, H. A. (1991). The upper critical ambient temperature in neonatal chicks. Poultry Science 70, 1882-1887.

Wiernusz, C. J. \& Teeter, R. G. (1993). Feeding effects on broiler thermobalance during thermoneutral and high ambient temperature exposure. Poultry Science 72, 1917-1924.

Williamson, R. A., Misson, B. H. \& Davison, T. F. (1985). The effect of exposure to $40^{\circ}$ on the heat production and the serum concentrations of triiodothyronine, thyroxine, and corticosterone in immature domestic fowl. General and Comparative Endocrinology 60, 178-186.

Yousef, M. K. (1985). Heat production: mechanisms and regulation. In Stress Physiology in Livestock, vol. 1, pp. 47-54 [M. K. Yousef, editor]. Florida: CRC Press. 